\title{
Žemės ūkio paskirties žemės sklypų rinkos aktyvumas pagal sklypo savybes
}

\section{Rimvydas Gaudèšius,}

\section{Pranas Aleknavičius}

Aleksandro Stulginskio universitetas, Studentu g. 11, LT-53361 Akademija, Kauno r.

El.paštas: rimvydas.gaudesius@nzt.lt; pranas.aleknavicius@gmail.com
Nuo 1991 m. Lietuvos Respublikoje vykdoma žemės reforma, kurios metu atkuriamos nuosavybès teisès į nacionalizuotą nekilnojamąjį turtą bei parduodama laisva valstybinè žemè. Tuo pat metu vyksta ir ūkininkavimo formų transformacija. Šiuo laikotarpiu žemès ūkio paskirties žemès įsigijimo poreikis naujai susikūrusiems ūkiams bei kitai paskirčiai padidino privačios žemès rinkos aktyvumą.

Moksliniame straipsnyje nurodytos pagrindinės privačios žemės rinkos aktyvumo priežastys ir nustatytos žemės sklypų savybès, kurios lemia žemès sklypų perleidimo aktyvumą rinkoje. Tyrimo metu siekiama įvertinti nustatytų ryšių stiprumą. Tyrimui pasirinkta agrarine teritorija greta Skuodo miesto. Nustatyta, jog patys žemės savininkai naudoja tik $46 \%$ jiems nuosavybės teise priklausančios žemės ūkio paskirties žemés. Tai turi ịtakos žemės perleidimo (ją naudojantiems ūkiniams subjektams) intensyvumui. Nustatyta, kad žemės ūkio paskirties žemės ¡̇sigijimo reguliavimas teisinemis priemonèmis gali paspartinti ūkinių struktūrų formavimosi procesą ir išvengti neracionalaus dirbamos žemès naudojimo.

Raktažodžiai: žemės sklypai, žemės rinka, žemės ūkio paskirties žemė, ūkiniai subjektai

\section{IVADAS}

Žemès ūkio paskirties žemè ypatinga tuo, kad ji yra pagrindinè žemès ūkio gamybos priemonè - pagrindas ūkininkų ūkiams ir kitoms ūkinèms struktūroms funkcionuoti. Šių ūkių efektyviai veiklai būtinas pakankamas žemès ūkio naudmenų plotas. Žemès ūkio paskirties žemès naudojimą apibūdina žemès sandorių apimtys, žemès ūkio gamybos intensyvumas, žemès naudojimo reglamentavimas ir kontrolè.

Žemès rinkos intensyvumą analizuojantys specialistai nurodo, kad sukūrus stabilias ūkines struktūras žemès rinka gali pasireikšti tik esant reikalui pakeisti ūkių žemès valdų ribas arba perleidžiant visą ūkị kitam asmeniui. Pakankamo žemès ploto neturintys ūkiniai subjektai siekia savo naudojamus ar savo ūkio plètrai reikalingus žemès plotus įsigyti nuosavybès teise. Aktyvus žemès rin- kos laikotarpis gali tęstis iki tol, kol visa žemè iš jos nedirbančių savininkų, taip pat ir žemès ūkio veiklai tinkama laisva valstybinè žemè pereis perspektyvių (konkurencingų) ūkių nuosavybèn arba ilgalaikei nuomai. Tačiau 2007 m. žemès ūkio paskirties žemès įsigijimo įstatymo pataisos panaikino svarbiausius saugiklius, kurie iki tol neleido įsigyti žemès jos perpardavinètojams. Toks procesas sulètino ūkių formavimąsi ir turi neigiamą ekonomini poveiki žemès ūkiui (Aleknavičius, 2011). Atsižvelgiant $\mathfrak{i}$ tai, teisiškai argumentuojama, kad net ir privačios žemès ūkio paskirties žemès įsigijimo sąlygos turi būti reglamentuojamos įstatymais. Siūloma vadovautis Lietuvos Respublikos (toliau - LR) Konstitucijos 46 straipsnio nuostata: „Valstybė reguliuoja ūkinę veiklą taip, kad ji tarnautu bendrai tautos gerovei“ ir LR Konstitucinio teismo konstatavimu: „Konstitucinis žemès apsaugos principas rodo, kad žemè traktuojama kaip 
visuotinè vertybè, turinti socialinę funkciją - tarnauti tautos gerovei. Visuomenei ne tas pats, kaip žemè naudojama, nes išsaugoti žemès produktyvumą yra visuotinis poreikis“, kuris nurodo galimybę ir prievolę valstybei aktyviai reguliuoti žemès rinką (Aleknavičius ir kt., 2011).

Žemès ūkio gamybos intensyvumą Lietuvoje lemia skirtingos sąlygos žemès ūkio veiklai vystyti. Dar sovietmečiu žemè pagal našumą buvo suskirstyta $\mathfrak{i}$ kelias kategorijas ir nuo jų priklausè žemès ūkio produkcijos supirkimo kainos. Atgavus nepriklausomybę, visa tai buvo panaikinta, ir nenašių žemių savininkai susidūrè su didelemis problemomis, nes jie buvo priversti konkuruoti su geresnèmis sąlygomis ūkininkaujančiais subjektais. Pajamos iš žemès ūkio veiklos nenašiose teritorijose buvo kelis kartus mažesnès, palyginti su derlingomis teritorijomis. Todèl kai kuriuose Lietuvos regionuose žemès ūkio veikla tapo nepelninga, žemès ūkio naudmenos buvo apleistos, prasidejo spartūs žemès renatūralizacijos procesai (Ribokas, 2013).

Žemès rinkos aktyvumą veikiančios žemès sklypų savybès turi itakos ir žemès rinkos vertei. Žemés ūkio paskirties žemé dažniausiai vertinama lyginamosios vertès metodu, kurio esmè yra palyginimas ir skaičiavimai, t. y. turto verte nustatoma palyginus analogiškuc objektų rinkos sandorių kainas, kartu atsižvelgiant $\mathfrak{i}$ nedidelius vertinimo objekto ir jo analogų skirtumus. Vertinant nekilnojamąj turtą analogiškam turtui derètų priskirti lyginamuosius objektus, kurie yra tapatūs vertinamam objektui visomis savo charakteristikomis arba kurių charakteristikų skirtumai nėra tiek reikšmingi, kad sukeltų kainų skirtumus, darytų i taką turto vertei. Esant reikšmingiems rinkos vertei lyginamųjų objektų charakteristikų skirtumams, būtinas pataisu ívertinimas (Tumelionis, 2013). Nustatyta, kad šių žemès sklypų fizinių savybių ir naudojimo sąlygų skirtumus lemia šie veiksniai:

- žemès sklypo konfigūracija ir patogumas dirbti žemès ūkio darbus;

- žemés naudojimo, valdymo ir disponavimo apribojimai, žemès servitutai;

- žemès sklypo teritorinis išsidèstymas sklypo savininkui reikalingų objektų atžvilgiu;

- žemès sklypo inžinerinè infrastruktūra, pagerinimas;

- galimybė naudoti žemės sklypą kitai veiklai (pvz., statyboms arba rekreacijai);
- žemès ūkio naudmenų našumas arba santykinis derlingumas (Čepulis ir kt., 2013).

Siekiant efektyviausio (maksimalaus) ir geriausio žemés sklypo panaudojimo (pagal turto vertinimo standartus - tai labiausiai tiketinas turto panaudojimas, kuris yra fiziškai įmanomas, tinkamai pagrịstas, juridiškai leistinas, finansiškai realus ir pajamingas bei ịvykdomas per laikotarpi iki penkerių metų), dalis žemès sklypų perleidžiami asmenims, numatantiems juos panaudoti urbanistinei plètrai. Ši procesą, kai užstatomi dideli priemiestinių teritorijų plotai, analizavę mokslininkai pažymi, kad „taškinis“ teritorijų planavimas ir spartus urbanizuotų teritorijų augimas veikia miestų ir kaimų kraštovaizdị, didina viešosios infrastruktūros poreiki, gamtos bei energetinių išteklių vartojimą, ekologinę taršą. Tačiau pagal LR teritorijų planavimo įstatymą nekilnojamojo turto plètros specialistai gali inicijuoti teritoriju planavimo procesą, rengti teritorijų planavimo dokumentus, tapti suinteresuotos visuomenès dalimi ir taip užtikrinti teritorijų planavimo dokumentu sprendinių atitikimą visuomenès ar valstybès interesams (Laurinavičius, Galinienè, 2011).

Kadangi arti įvairaus dydžio miestų dalis žemès sklypų yra panaudojami tik žemès ūkio veiklai, kiti - gyvenamajai statybai ar ūkinei-komercinei veiklai, arba kitiems tikslams, jų efektyviausias panaudojimas gali būti nustatomas turint ilgalaikio teritorijos tvarkymo priemones numatantį bendrąji planą ir vadovaujantis analitiniais skaičiavimais. Vienas iš žemès sklypu perspektyvinio panaudojimo optimizavimui rekomenduojamų skaičiavimo būdų yra daugiakriterinis vertinimo metodas, kuris taikomas nekilnojamojo turto analizei: nustatyti objekto naudingumą, prioritetiškumą vienas kito atžvilgiu, veiksnių, lemiančių nekilnojamojo turto vertę, reikšmingumus, parduotų objektų ir vertinamojo objekto konkurenciškumą (Malienè ir kt., 1999).

Tyrimo tikslas - identifikuoti ryšius bei jų stiprumą tarp žemės sklypo savybių ir jo aktyvumo nekilnojamojo turto rinkoje.

Tyrimo objektas - agrarinès teritorijos dalis (420 ha) greta Skuodo miesto esančiose seniūnijose.

Tyrimo metodai - duomenų analizès, sintezès, indukcijos, grafinio modeliavimo (su AutoCAD programa), koreliacinès analizès (su Excel programa), abstrahavimo ir tikimybių teorijos. Tyrimams panaudoti Nacionalinès žemès tarnybos 
prie Žemès ūkio ministerijos (toliau - NŽT), Nacionalinès mokejjimo agentūros prie Žemès ūkio ministerijos (toliau - NMA) ir VIt Registrų centro (toliau - RC) duomenys apie 120 žemès sklypų.

\section{TYRIMO REZULTATAI}

Iš mokslinès literatūros matyti, kad pagrindinès žemès ūkio paskirties žemès rinkos aktyvumo priežastys gali būti: žemès sklypų, ì kuriuos atkurtos nuosavybès teisès, perleidimas kitiems asmenims dèl to, kad jų savininkai neturi galimybès naudoti tokiu būdu igytą turtą; ūkių naudojamos žemès plotų (žeménaudų) ar žemès valdų stambinimas; žemès sklypų perpardavinejjimas naudojantis urbanizacijos plètra.

Nekilnojamojo turto specialistai mano, kad nekilnojamasis turtas dažniausiai yra perleidžiamas kitam savininkui, kai jis randa būdą, kaip efektyviau ši turtą išnaudoti bei gali daugiau $\mathfrak{i}$ ji investuoti. Todèl ekonomistai galètų teigti, kad kuo didesnis tokių sandorių skaičius šalyje, tuo akivaizdesnè nauda šalies ekonomikai.

Pagal LR teritorijos bendrojo plano (LR..., 2002) nacionalinès regioninès politikos organizavimo sprendinius ir urbanistinị karkasą Skuodo miestas priskiriamas 3 lygmens lokaliniam centrui, aplink kuri nenumatoma aktyvi urbanizacija. LR teritorijos bendrajame plane Skuodo rajonas priskiriamas Žemaitijos plynaukštei, kurioje yra galimybė teritoriją naudoti žemès ūkiui, nes dirvožemio jautrumas intensyviam žemès dirbimui nedidelis.
Čia yra vidutiniškai našios žemès, todèl siūloma derinti ịvairaus dydžio ir tipų ūkius.

Atsižvelgiant $\mathfrak{i}$ LR teritorijos ir Skuodo rajono savivaldybès teritorijos (Skuodo..., 2009) bendruosiuose planuose numatytą urbanistinę plètrą darytina išvada, kad žemès ūkio paskirties žemès sklypus, esančius greta Skuodo miesto, supirkinèti dèl perpardavinejjimo, numatant paskirtị keisti $\mathfrak{i}$ gyvenamąją, nėra perspektyvu.

Norint išsiaiškinti, ar žemès ūkio paskirties žemès sklypų pardavimų rinka aktyvi dèl stambesnių ùkinių struktūrų formavimosi, reikia analizuoti nuosavybès teisių pasiskirstymą vietoveje. Tiriamieji žemès sklypai yra išsidėstę skirtingose teritorijos vietose grupelèmis (1 pav.), kad būtu galima įvertinti rinkos aktyvumą pagal kuo daugiau kriterijų; pavyzdžiui, atstumas nuo miesto ( 2 pav. izolinijos išdèstytos kas $500 \mathrm{~m}$ ), atstumas nuo pagrindinio kelio ( 3 pav. izolinijos išdèstytos kas $500 \mathrm{~m}$ ), tolimesnès žemès sklypo naudojimo galimybès pagal bendrajji rajono planą, žemès našumo balas ir t. t.

Tiriamojoje teritorijoje, išnagrinejjus žemès sklypų nuosavybès dokumentus ir NMA duomenų bazèje turimus duomenis apie faktiško žemès sklypų naudojimo deklaravimą, paaiškejjo, kad žemès sklypus naudoja $46 \%$ savininku. Be to, 13,8 \% žemės sklypu valdomi bendrosios dalinès nuosavybès teise. Likusius žemès sklypus naudoja kiti asmenys, iš kurių tik maža dalis (35 \%) yra sudariusi ir Nekilnojamojo turto registre įregistravusi oficialias sutartis, patvirtinančias jų teisę šią žemę

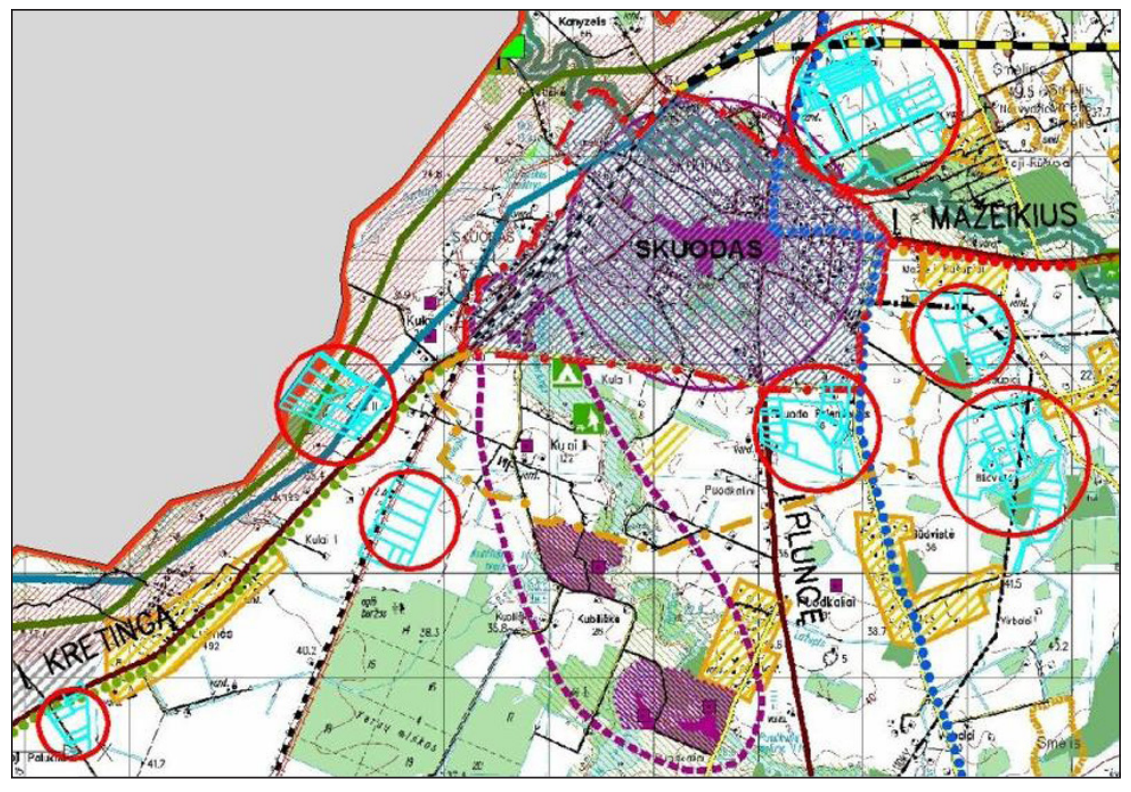

1 pav. Tiriamųjų žemès sklypu išsidèstymas bendrajame plane

Fig. 1. Land plots in the general plan of the region 


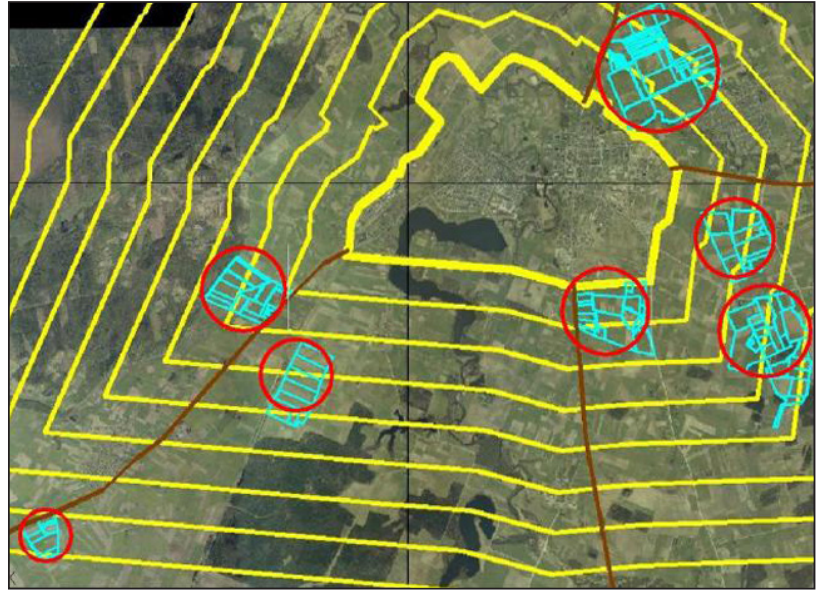

2 pav. Tiriamųjų žemès sklypų išsidèstymas matuojant atstumą nuo miesto

Fig. 2. Location of the land plots measuring the distance from the city

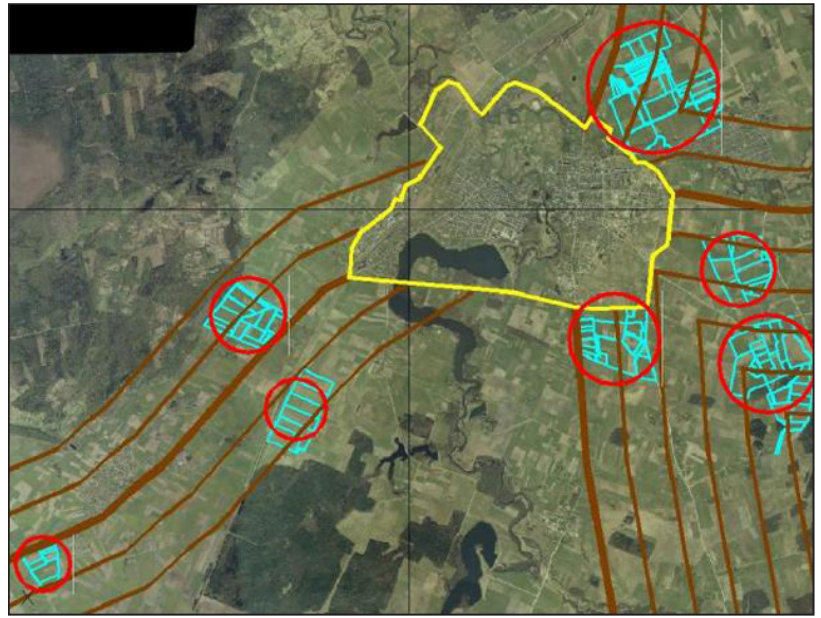

3 pav. Tiriamųjų žemès sklypų išsidėstymas matuojant atstumą nuo krašto kelio

Fig. 3. Location of the land plots measuring the distance from the road

naudoti (3 žemès panaudos sutartys ir 16 žemès nuomos sutarčių). Didžioji teritorijos dalis pagal nuosavybès teises priklauso fiziniams asmenims ir tik 4,3\% sklypų turi ịsigiję juridiniai asmenys.

LR Žemès ịstatymo (Lietuvos... 1994) 4 skyriuje aprašytos žemès naudojimo sąlygos, t. y. žemès savininkų ir kitų naudotojų pareigos, specialiosios naudojimo sąlygos, servitutai, pagrindinès žemès naudojimo paskirties ir būdo nustatymo bei keitimo tvarka.

Pagrindinè žemès naudojimo paskirtis - teritorijos gamtinių ypatumų, tradicinès žmonių veiklos, socialinès ir ekonominès plètros poreikio nulemta pagrindinio žemès naudojimo kryptis, numatyta teritorijų planavimo dokumente ar žemès valdos projekte, nuo kurios priklauso šios teritorijos planavimo ir žemès naudojimo sąlygos. Žemès ịstatyme taip pat nurodyta, kad pagrindinè žemès naudojimo paskirtis ir būdas (būdai) Vyriausybès nustatyta tvarka nustatomi formuojant naujus žemès sklypus. Šiems žemès sklypams nustatyta pagrindinè žemès naudojimo paskirtis ir (ar) būdas (būdai) keičiami žemès savininkų, valstybinès žemès patikètinių ar istatymų nustatytais atvejais kitų subjektų prašymu pagal teritorijų planavimo dokumentus.

Remiantis Skuodo rajono bendruoju planu, tiriamųjų žemès sklypų paskirtis galima keisti 18 sklypu - juos paimant naudoti visuomenès poreikiams, įveisiant mišką ar užstatant statiniais. Atsižvelgiant $\mathfrak{i}$ teoriją, kad daiktas rinkoje tampa paklausesnis, kai ji galima panaudoti kitai (naudingesnei) veiklai, galima manyti, kad šie žemès sklypai turètų būti perleidžiami greičiau ir (ar) dažniau dèl jų poreikio investuotojams.

Specialiosios žemès naudojimo sąlygos - tai nustatyti ūkinès ir (ar) kitokios veiklos apribojimai. Iš tiriamųjų objektų nebuvo nustatyta nè vieno, kuriam nebūtų taikoma jokia žemès naudojimo specialioji sąlyga. Vidutiniškai žemès sklypui buvo nustatyta po 3 apribojimus, o daugiausia net 6 (tokių sklypų buvo 6). Atsižvelgiant ị tai, kad skirtingos specialiosios žemès naudojimo sąlygos skirtingai apriboja veiklą (Lietuvos... 1992) žemès sklype, yra tikètina, kad žemès sklypas su kuo daugiau apribojimų ir didesnių jų taikomu plotu žemès rinkoje bus mažiau aktyvus.

Galima iškelti dar vieną hipotezę - kuo didesnis žemès sklypo plotas, tuo jis aktyvesnis rinkoje, nes tai vientisas didelis plotas, kuriame patogiau ir naudingiau ūkininkauti, taip pat ji galima padalyti i smulkesnius ir sklypus perparduoti. Tyrimo metu apskaičiuota, kad vidutinis tiriamojo žemès sklypo plotas - 3,61 ha, didžiausias - 30,91 ha, o mažiausias $-0,28$ ha. Iš visų šių žemès sklypų 10 buvo performuoti.

Tiriamieji žemès sklypai pakankamai aktyvūs nekilnojamojo turto rinkoje, kad būtų galima nustatyti dažniausius perleidimo pagrindus, rinkos aktyviausius laikotarpius ir t. t. Daugiausia kartų nuosavybès teisès perleistos 4 žemès sklypams (po 3 kartus), o 40,5 \% žemès sklypų kitiems asmenims neperleisti nẻ karto. Dažniausias perleidimo 
pagrindas - paveldejimas (36 kartai), po to - pirkimo-pardavimo (35) ir dovanojimo (26) sutartys. Taip pat užregistruota ir viena mainų sutartis. Pagal atliktus skaičiavimus darytina išvada, kad pirmą kartą ịsigyjama nuosavybẻ buvo išlaikoma vidutiniškai 5 metus. Pirmasis nuosavybès teisių perleidimas dažniausiai vyko dèl paveldejjimo (31), po to dèl pirkimo-pardavimo (19) ir dovanojimo (18). Antrasis perleidimas jau dažniau vyko dèl pirkimo-pardavimo (12) ir dovanojimo (5), penki paveldejimo atvejai ir vienas mainų. Trečiojo perleidimo juridiniu pagrindu tapo pirkimo-pardavimo (3) ir dovanojimo (1) sutartys.

Iš sudarytų privačios žemės perleidimo sutarčių (pirkimo-pardavimo, dovanojimo, mainų) datų galima daryti išvadą, kad aktyviausias rinkos laikotarpis buvo 2005-2008 m., pirmaujantys pagal sandorių skaičiu - 2007 m. (4 pav.). Tai sutampa su didesne Europos Sajungos lèšu parama žemès ūkiui pagal Lietuvos kaimo plètros 2007-2013 m. programos priemones ir su vèliau prasidejusia ekonomine krize. Taip pat apskaičiuota, kad net $14 \%$ žemès sklypų buvo perleista kitiems asmenims jau po metų arba dar greičiau nuo pirmosios nuosavybés igijimo. Toks staigus pirmojo savininko sprendimas perleisti nuosavybès teises kitam asmeniui gali būti paaiškinamas tuo, kad jis nèra patenkintas suprojektuotu žemès sklypu ir (ar) neketina užsiimti toje vietoje jokia ūkine veikla.

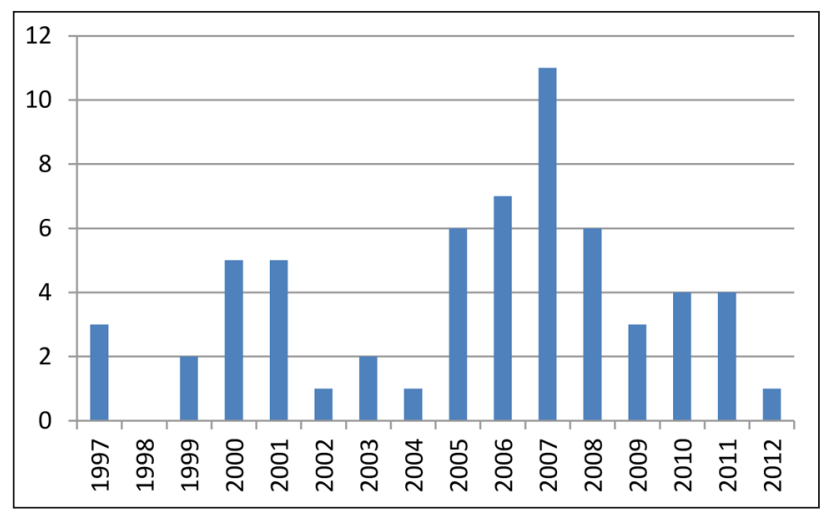

4 pav. Žemės sandorių skaičius atitinkamais metais. Sudaryta remiantis RC duomenimis

Fig. 4. The number of the land transactions in the relevant year. Formed by the RC data

Žemès ūkio paskirties žemès sklypų aktyvumo rinkoje priežastys buvo analizuojamos atsižvelgiant $\mathfrak{i}$ ịvairius duomenis ir sklypų savybes, kurie gali lemti žemės sklypo patrauklumą pirkejjams (1 lentelè). Dèl didelio kiekio lenteleje pateikta tik dalies (penktadalio) tiriamųjų žemès sklypų duomenys.

Ieškant ryšių ir jų stiprumo tarp turimų duomenų tikslinga naudoti koreliacijos metodą, tačiau būtina pažymèti, kad tai labiau siejama su statistiniu ryšiu, bet ne su realiu priežastingumu.

Visų pirma analizuojama ir sklaidos diagramoje (5 pav.) pavaizduota pardavimu priklausomybè nuo žemès sklypui nustatytų apribojimų skaičiaus. Iš šios sklaidos diagramos matyti, kad čia pasireiškia neigiamas tiesinis ryšys, o koreliacijos koeficientas lygus -0,54 (vidutinio stiprumo ryšys). Todèl darytina išvada, kad žemès sklypui nustatytas kuo didesnis apribojimų skaičius turi vidutinę neigiamą reikšmę ji parduodant.

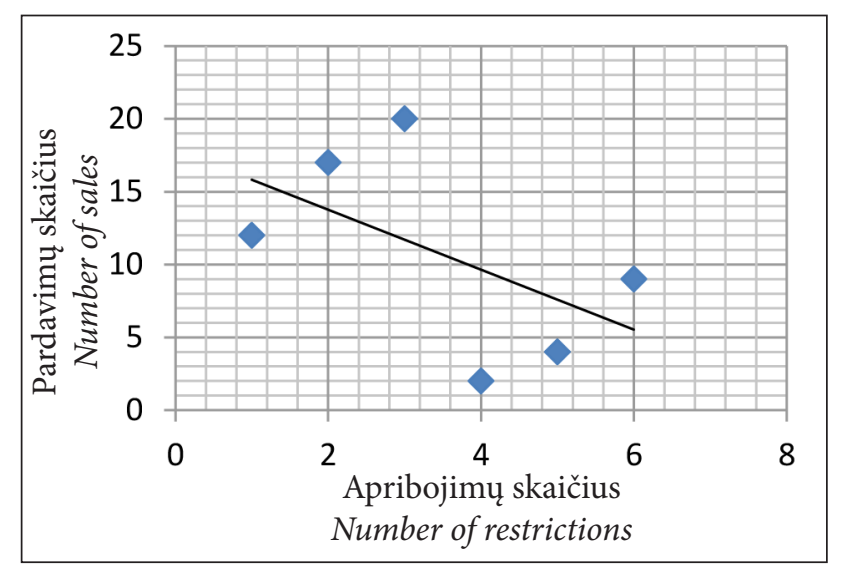

5 pav. Pardavimų priklausomybė nuo apribojimų skaičiaus

Fig. 5. Dependency of the land plots sales on the number of restrictions

Antroje taškų sklaidos diagramoje (6 pav.) pavaizduota pardavimų priklausomybė nuo žemès sklypo našumo balo. Čia nustatytas teigiamas tiesinis ryšys, kurio koreliacijos koeficientas lygus 0,31 (silpnas ryšys). Atsižvelgiant $i$ šiuos skaičiavimus galima teigti, kad didesnis žemès sklypo našumo balas turi teigiamą ịtaką sklypo pardavimui, tačiau silpną.

Trečioje taškų sklaidos diagramoje (7 pav.) pavaizduotas taškų išsidèstymas plokštumoje, kurie parodo žemès ūkio paskirties žemès sklypų pardavimų priklausomybę nuo žemès sklypo ploto. Čia matomas neigiamas tiesinis ryšys, kur koreliacijos koeficientas lygus $-0,70$ (stiprus ryšys). Tai reiškia, 
Le ntelè. Žemės sklypų savybès, pagal kurias vertinama jų paklausa rinkoje

Table. Properties of the land plots affecting the market demand

\begin{tabular}{|c|c|c|c|c|c|c|c|c|c|c|}
\hline \multirow{2}{*}{ 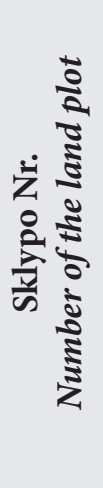 } & \multirow{2}{*}{ 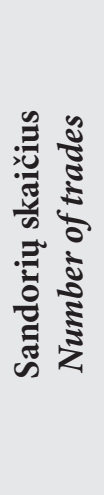 } & \multirow{2}{*}{ 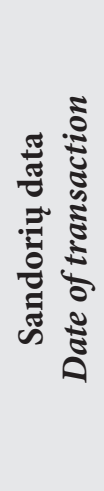 } & \multirow{2}{*}{ 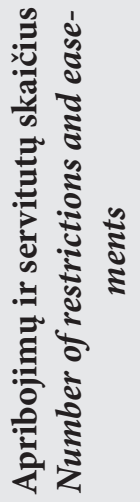 } & \multirow{2}{*}{ 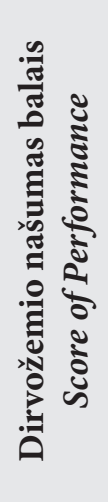 } & \multirow{2}{*}{$\begin{array}{l}\frac{3}{3} \\
\frac{5}{0} \\
\frac{\tilde{J}}{0} \\
\frac{0}{2}\end{array}$} & \multirow{2}{*}{ 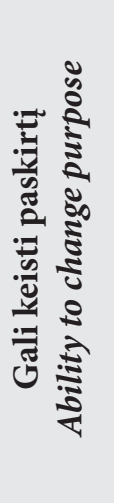 } & \multicolumn{2}{|c|}{$\begin{array}{l}\text { Atstumas km } \\
\text { Distance, } \mathrm{km}\end{array}$} & \multirow{2}{*}{ 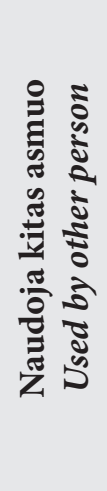 } & \multirow{2}{*}{ 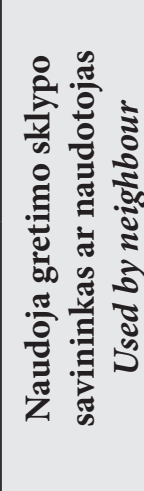 } \\
\hline & & & & & & & 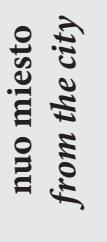 & 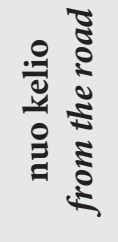 & & \\
\hline 1 & 1 & 2001 & 3 & 45 & 5,20 & Taip & 1 & 0,5 & + & - \\
\hline 2 & 1 & 2011 & 2 & 46 & 1,48 & $\mathrm{Ne}$ & 1 & 0,5 & + & - \\
\hline 3 & 2 & $\begin{array}{l}2007 \\
2008\end{array}$ & 3 & 52 & 0,30 & $\mathrm{Ne}$ & 0,5 & 0,5 & + & - \\
\hline 4 & 1 & 2005 & 1 & 44 & 3,96 & $\mathrm{Ne}$ & 1,5 & 1,5 & + & - \\
\hline 5 & 1 & 2010 & 1 & 44 & 0,58 & $\mathrm{Ne}$ & 1 & 1 & + & + \\
\hline 6 & 1 & 2010 & 3 & 44 & 3,41 & $\mathrm{Ne}$ & 1,5 & 1,5 & + & + \\
\hline 7 & 2 & $\begin{array}{l}1999 \\
2006\end{array}$ & 2 & 38 & 7,24 & $\mathrm{Ne}$ & 1 & 1 & - & + \\
\hline 8 & 1 & 2007 & 3 & 36 & 7,9 & $\mathrm{Ne}$ & 1 & 1 & + & - \\
\hline 9 & 2 & $\begin{array}{l}1999, \\
2006 \\
\end{array}$ & 2 & 38 & 6,44 & Taip & 1 & 1 & + & + \\
\hline 10 & 1 & 2000 & 3 & 41 & 5,45 & $\mathrm{Ne}$ & 1 & 1 & + & + \\
\hline 11 & 1 & 2007 & 3 & 48 & 2,25 & $\mathrm{Ne}$ & 1,5 & 1 & + & - \\
\hline 12 & 1 & 2012 & 3 & 39 & 1,57 & $\mathrm{Ne}$ & 1,5 & 2 & + & + \\
\hline 13 & 2 & $\begin{array}{l}2007 \\
2008 \\
\end{array}$ & 5 & 46 & 13,8 & Taip & 1,5 & 1,5 & - & - \\
\hline 14 & 2 & $\begin{array}{l}2001 \\
2006\end{array}$ & 3 & 36 & 4,6 & Taip & 2 & 2,5 & - & + \\
\hline 15 & 2 & $\begin{array}{l}2001, \\
2006\end{array}$ & 1 & 37 & 4,27 & $\mathrm{Ne}$ & 2 & 2,5 & - & + \\
\hline 16 & 3 & $\begin{array}{l}2005 \\
2007 \\
2011\end{array}$ & 2 & 38 & 2,75 & $\mathrm{Ne}$ & 2 & 3 & - & + \\
\hline 17 & 2 & $\begin{array}{l}2005 \\
2006\end{array}$ & 3 & 48 & 1,0 & $\mathrm{Ne}$ & 0,5 & 0,5 & + & - \\
\hline 18 & 1 & 2007 & 1 & 46 & 7,84 & $\mathrm{Ne}$ & 0,5 & 0,5 & + & - \\
\hline 19 & 1 & 1997 & 3 & 46 & 0,75 & $\mathrm{Ne}$ & 0,5 & 1 & + & - \\
\hline 20 & 2 & $\begin{array}{l}2001 \\
2011 \\
\end{array}$ & 6 & 48 & 5,0 & $\mathrm{Ne}$ & 1 & 0,5 & + & - \\
\hline 21 & 1 & 2007 & 5 & 40 & 2,89 & $\mathrm{Ne}$ & 1 & 0,5 & + & - \\
\hline 22 & 3 & $\begin{array}{l}2007, \\
2008, \\
2009,\end{array}$ & 6 & 44 & 5,0 & $\mathrm{Ne}$ & 1,5 & 1 & + & - \\
\hline 23 & 1 & 2012 & 3 & 41 & 2,5 & Taip & 1 & 0,5 & + & - \\
\hline 24 & 2 & $\begin{array}{l}2005 \\
2010\end{array}$ & 2 & 42 & 6,82 & $\mathrm{Ne}$ & 1,5 & 1 & + & - \\
\hline 25 & 3 & $\begin{array}{l}2007 \\
2008, \\
2009\end{array}$ & 3 & 50 & 6,82 & $\mathrm{Ne}$ & 2 & 1 & + & - \\
\hline
\end{tabular}




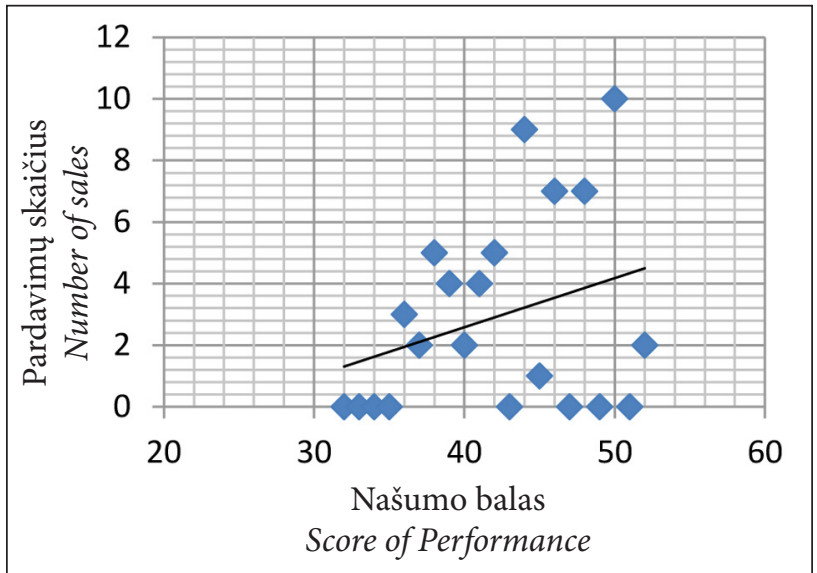

6 pav. Pardavimų priklausomybè nuo našumo balo Fig. 6. Dependency of the land plots sales on the Performance Score

kad didesnį žemès sklypą yra sunkiau parduoti. Pagrindinis rinkos aktyvumas pasireiškia tarp sklypų iki 10 ha, tačiau reikia paminèti, kad didelių sklypų yra suprojektuota labai mažai ir tiriamojoje teritorijoje vidutinis žemès sklypo plotas siekia 3,61 ha, todèl pavieniai didelių sklypų pardavimai gali šiek tiek iškreipti ryšio stiprumą.

Žemès ūkio paskirties žemės sklypų pardavimų priklausomybe nuo atstumo iki artimiausio miesto ir iki artimiausių krašto kelių pavaizduota ketvirtoje diagramoje (8 pav.). Matyti, kad abiem atvejais (mèlyni taškai (rombai) - atstumas nuo miesto; žali (trikampiai) - nuo kelio) išryškẻja neigiamas tiesinis ryšys, koreliacinis ryšys dèl atstumo nuo kelio $(-0,81$ (stiprus ryšys)) ir nuo miesto $(-0,75$ (stiprus)) yra panašaus stiprumo.

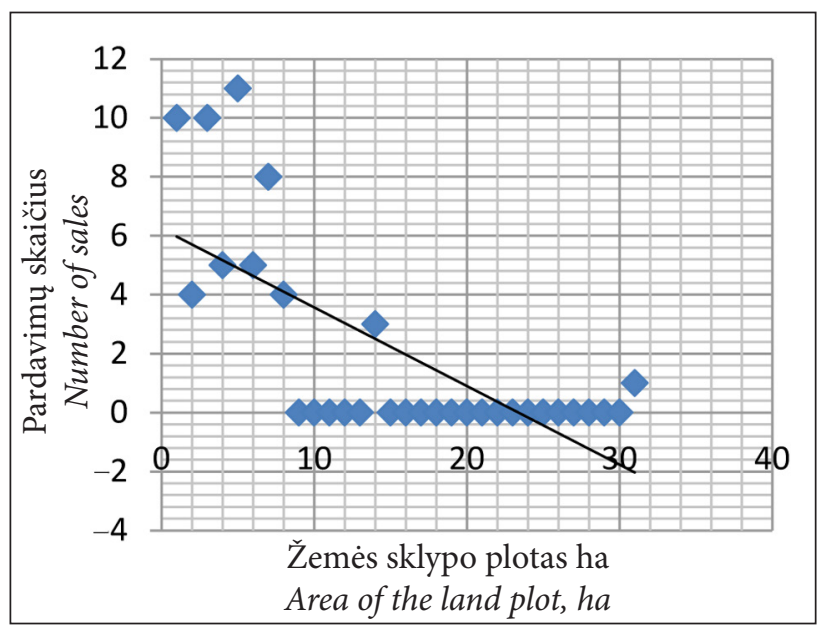

7 pav. Pardavimų priklausomybè nuo sklypo ploto

Fig. 7. Dependency of the land plots sales on the land area

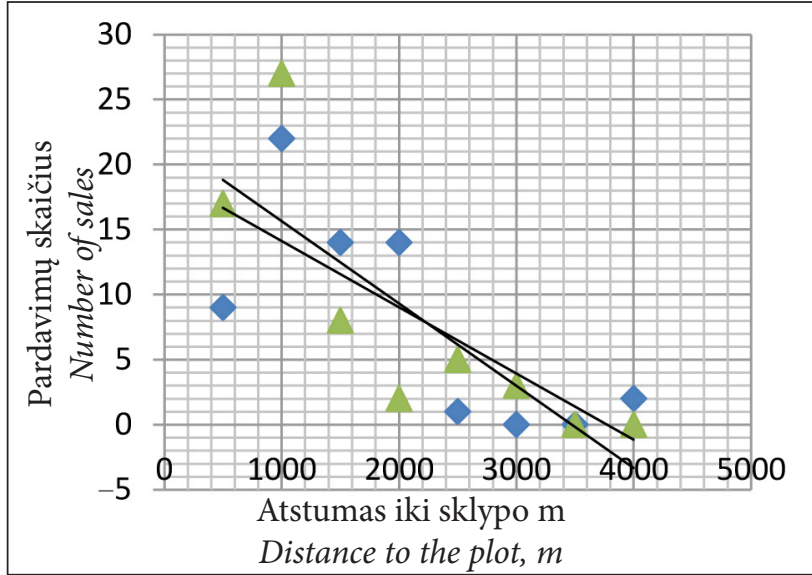

8 pav. Pardavimų priklausomybè nuo atstumo iki miesto ir kelio

Fig. 8. Dependency of the land plots sales on the distance from the town and the road

Analogiška priklausomybė nustatyta ir lyginant parduotų žemès sklypų kainas. Išanalizavus 28 žemès sklypų rinkos kainos ryšio su ją galinčiais lemti veiksniais, nustatyta:

- silpna žemès našumo balo (36-52 balų intervalas) ittaka - koreliacijos koeficientas $r=0,22$. Didejjant žemès našumui, kaina irgi didejja;

- silpna žemès sklypo dydžio (0,3-30,9 ha ploto intervalas) ittaka - koreliacijos koeficientas $r=0,17$. Didejjant žemès sklypo plotui, kaina dideja;

- vidutinio stiprumo žemès sklypo atstumo nuo valstybinių kelių $(0,5-2,5 \mathrm{~km}$ intervalas) įtaka - koreliacijos koeficientas $r=0,44$. Didejjant atstumui, kaina mažejja;

- stipri žemès sklypo atstumo nuo miesto $(0,5-$ $4,0 \mathrm{~km})$ itaka - koreliacijos koeficientas $r=0,71$. Didejant atstumui, kaina mažeja.

Siekiant rasti žemés sklypo aktyvumo rinkoje priklausomybę nuo kitų kriterijų, tikslinga naudoti tikimybiu teorijos (Tikimybiu teorija..., 2012, 39 p.) formulę, nes reikšmių pasirinkimas sumažèja iki dviejų. Vadinasi, galima tik apskaičiuoti, kuri savybè turi didesnę tikimybę:

$$
P(A)=\frac{m}{n} ;
$$

$P$ - tikimybė; $A$ - įvykis (savybè); $m$ - palankūs ìvykiai; $n$ - visi elementarūs ịvykiai.

Žemès sklypai atsižvelgiant ị teorines rekomendacijas turètų būti formuojami racionalių, taisyklingų formų, tačiau dèl įvairių priežasčių visada to 
padaryti nepavyksta. Taisyklingos formos sklypus yra patogiau dirbti, tačiau ar jie gali būti parduoti rinkoje, tikimybe், nustatyta pagal 1 formulę, yra

$P($ taisyklingos formos $)=\frac{27}{65}=0,42 ;$

$P($ netaisyklingos formos $)=\frac{20}{51}=0,39$.

Apibendrinus duomenis, kiek buvo parduota taisyklingos formos ir netaisyklingos formos žemès sklypų, nustatyta, kad šiek tiek didesnè tikimybė parduoti taisyklingos formos žemès sklypą, tačiau abi tikimybès labai nutolusios nuo vieneto, kas galètų reikšti, kad šis kriterijus nèra labai reikšmingas.

Kita parduodant aktuali žemés sklypo savybè - tai galimybė ji naudoti kitai, ne žemès ūkio paskirčiai. Norint sužinoti, ar tai tikrai reikšminga ir kokia tikimybė yra didesnè - parduoti žemès sklypą su galimybe pakeisti naudojimo paskirtị ar be tokios galimybès, vèl panaudota tikimybiu teorija:

$P($ galima keisti paskirti $)=\frac{10}{18}=0,56 ;$

$P($ negalima keisti paskirties $)=\frac{37}{98}=0,38$.

Atlikti skaičiavimai parodè, kad akivaizdžiai didesnè tikimybė yra parduoti žemès sklypą, kai ji galima panaudoti ir kitai paskirčiai. Tarp šių dviejų lyginamujuc kriterijų ne tik akivaizdus tikimybių skirtumas, bet, galima matyti, kad vienas iš jų artimesnis vienetui, taigi šis kriterijus gana stiprus.

Tyrimo metu taip pat nustatyta, kad kaimo vietoveje palaipsniui formuojasi stambesnès, kompaktiškesnès ūkinès struktūros. Teritorijoje keletas savininkų nuosavybès teise valdo po 5-7 žemès sklypus, tačiau jų plotų suma neviršija didžiausių tyrime buvusių sklypų ploto. Pavyzdžiui, 7 žemès sklypai sudaro 12,13 ha, 6 sklypai - 12,35 ha, 5 sklypai $-9,24$ ha ir pan. Taip pat nustatyta, kad šiuo atveju didžiųjų pavienių žemès sklypų patys savininkai nevaldo. Kita ūkinè struktūra formuojasi iš kitų asmenų naudojamų žemès sklypų, kurių teritorijoje tas pats naudotojas valdo po 3-4. Tačiau plotas taip pat svyruoja apie 10 ha. Pavyzdžiui, 4 žemés sklypai sudaro 11,3 ha, 3 sklypai $-5,53$ ha, 2 žemès sklypai - 12,5 ha ir t. t.

Siekiant reguliuoti žemès ūkio paskirties žemès pardavimus, kad nebūtų stabdomas žemès ūkio struktūrų formavimasis, o žemè nebūtų perpar- davinèjama tik dèl užstatymo galimybès, $2014 \mathrm{~m}$. priimtos įstatymų pataisos (Lietuvos... 2014), kurios suteikia galimybę žemès ūkio paskirties žemę pirmumo teise ísigyti asmenims, užsiimantiems aktyviu ūkininkavimu. Privatus asmuo, norèdamas parduoti nuosavybès teise valdomą žemès ūkio paskirties žemès sklypą, kreipiasi į NŽT, kuri atlieką administracinę procedūrą. Jos metu yra informuojami besiribojančių žemès ūkio paskirties žemès sklypų savininkai apie galimybę pirmumo teise įsigyti parduodamą žemès sklypą. Jei atsiranda pageidaujančių, tai jie privalo NŽT teritoriniam padaliniui pateikti dokumentus, kurie patvirtintų, kad asmuo atitinka keliamus reikalavimus ir gali įsigyti žemès ūkio paskirties žemès. Jei tokių nèra, tai savininkas žemès sklypą parduoda savo nuožiūra pasirinktam pirkejjui, tačiau tik tokiems asmenims, kurie gali įsigyti žemès ūkio paskirties žemès.

LR žemès ūkio paskirties žemès įsigijimo įstatymo (Lietuvos... 2014) 2 straipsnyje nurodyta, kad teisę ịsigyti žemès ūkio paskirties žemès turi:

1) fizinis asmuo, turintis profesinių igūdžių ir kompetencijos. Tokiu asmeniu laikomas ne mažiau kaip 3 metus per paskutinius dešimt metų iki žemès ūkio paskirties žemès ịsigijimo sandorio sudarymo dienos žemès ūkio veiklą vykdęs (įskaitant studijų ir (ar) mokymosi igyjant žemès ūkio išsimokslinimą laiką) ir žemès ūkio naudmenas bei pasèlius deklaravęs fizinis asmuo, kuris LR ūkininko ūkio įstatymo nustatyta tvarka yra įregistravęs ūkininko ūkị arba turi žemès ūkio išsimokslinimo diplomą. Šios nuostatos netaikomos jauniesiems ūkininkams - iki 40 metų, gavusiems NŽT leidimą îsigyti žemès ūkio paskirties žemès;

2) juridinis asmuo ar kita organizacija, ne mažiau kaip 3 metus per paskutinius dešimt metų iki žemès ūkio paskirties žemès ịsigijimo sandorio sudarymo dienos žemès ūkio veiklą vykdęs ir žemès ūkio naudmenas bei pasèlius deklaravęs, jeigu jo pajamos iš žemès ūkio veiklos sudaro daugiau kaip $50 \%$ visu gautu pajamų ir jeigu jo ekonominis gyvybingumas gali būti įrodytas LR Žemès ūkio ministerijos nustatyta tvarka ivvertinus šio asmens perspektyvas.

Anksčiau išvardyti reikalavimai netaikomi ir NŽT leidimas neprivalomas, kai nuosavybèn įsigyjama tiek žemès, kad sudarius žemès ūkio paskirties žemès perleidimo sandorị asmeniui priklausantis žemès ūkio paskirties žemès plotas Lietuvos 
teritorijoje neviršija 10 ha kartu su jau turima tos pačios paskirties žeme; kai įsigyjami žemès ūkio paskirties žemès sklypai naudojami nuosavybès teise turimiems ar kartu su žemès sklypu įsigyjamiems statiniams ir i̇renginiams eksploatuoti; kai Žemès įstatymo nustatyta tvarka pirmumo teise perkami žemès sklypai, priskirti žemès konsolidacijos projekto teritorijai; kai pagal įstatymą perkami tarp nuosavybès teise valdomų žemès sklypu įsiterpę valstybinès žemès ūkio paskirties žemès plotai arba kai privatizuojama naudojama asmeninio ūkio žemé, arba kai įsigyjamas žemès sklypas patenka $\mathfrak{i}$ teritoriją, kurioje pagal savivaldybès lygmens ir vietovès lygmens bendruosius planus žemę numatyta naudoti ne žemès ùkio veiklai.

Taip pat istatymu yra ribojamas ir bendras turimas žemés plotas, t. y. asmuo ar susiję asmenys gali įsigyti tiek žemès Lietuvos teritorijoje, kad bendras jų iš valstybès ịsigytos žemès ūkio paskirties žemès plotas nebūtų didesnis kaip 300 ha, o bendras jiems priklausantis iš valstybès ir kitų asmenų i̊sigytos žemès ūkio paskirties žemès plotas nebūtų didesnis kaip 500 ha. Šios patikslinto įstatymo nuostatos gali padidinti žemès perleidimų ją naudojantiems ūkiams kiekị ir sumažinti issigytų žemès sklypų pakartotinių perleidimų kitiems asmenims skaičių.

\section{IŠVADOS IR PASIŪLYMAI}

1. Tyrimo metu paaiškejo, kad tiriamojoje teritorijoje didelè dalis žemès savininkų savo nuosavybès teise turimą žemę linkę išsaugoti ilgesnị laikotarpí, nes $40,5 \%$ žemès sklypų nẻ karto nèra perleista kitiems asmenims, nors daugumą (54\%) žemès sklypų faktiškai naudoja ne tikrieji žemès sklypų savininkai. Taip pat nustatyta, kad pirmasis žemès sklypo perleidimas dažniausiai buvo dèl paveldejjimo, o jau kiti - dèl pirkimo-pardavimo ir dovanojimo sutarčių.

2. Dauguma žemės ūkio paskirties žemės sklypu parduota 2005-2008 m. laikotarpiu, kai valstybeje buvo ekonominis pakilimas. Tai leidžia daryti išvadą, kad savininkai, kurie neplanavo užsiimti žemès ūkio veikla, laikè šiuos savo nekilnojamojo turto objektus iki progos, kai už juos bus mokama brangiausiai.

3. Atlikus koreliacinius ir tikimybių skaičiavimus paaiškèjo, kad žemès sklypų savybių ryšiai pagal stiprumą (nuo stipriausio) išsidèsto taip: atstumas nuo kelio, atstumas nuo miesto, sklypo plotas, galimybe keisti paskirti, nustatytu apribojimų skaičius, sklypo konfigūracija, našumo balas. Jei žemės sklypas yra kuo arčiau pagrindinio kelio, miesto, nedidelio ploto ir yra galimybè naudoti kitai paskirčiai jis rinkoje bus labai aktyvus. Tuo tarpu kiti žemès ūkio paskirties žemès sklypai, nors ir pakankamai našūs, taisyklingos formos bei turintys nedaug naudojimo apribojimų, kol kas yra mažai paklausūs.

4. Atsižvelgiant ị tai, kad tiriamieji žemès sklypai buvo suformuoti skirtingu laikotarpiu (vadinasi, jų dalyvavimas nekilnojamojo turto rinkoje laiko atžvilgiu nebuvo visiškai vienodas), taip pat siekiant gauti tikslesnius rodiklius, analogiškus tyrimus tikslinga atlikti kitose geografinèse vietovèse.

5. Valstybė, istatymais reguliuodama žemès ūkio paskirties žemès ịsigijimo rinką, sudaro galimybę aktyviai ūkininkaujantiems asmenims padidinti savo turimas žemès valdas, taip pat stabdo žemès sklypų perpardavinejjimą ir jų nenaudojimą dèl užstatymo galimybès. Patikslinto įstatymo ịgyvendinimas analizuojamoje teritorijoje leistų padidinti besiformuojančių ùkių žemès valdų stabilumą.

Gauta 20150528 Priimta 20150914

\section{LITERATŪRA}

1. Aleknavičius P. 2011. Lietuvos žemès ūkio subjektų žeménaudų formavimo racionalumo pagrindimas vadybiniu požiūriu. Iš: Agrariniu teritoriju tvarkymo problemos. Sud. P. Aleknavičius. Kaunas. P. 37-64.

2. Aleknavičius P., Aleknavičius M., Tumelionis A. 2009. Privačios žemès ūkio paskirties žemès perleidimų priežastys ir tendencijos. Vagos: mokslo darbai. Nr. 84(37). P. 46-55.

3. Čepulis P., Deveikis S., Raguckas V. 2013. Nacionaliniai turto ir verslo vertinimo standartai. Projektas 2010. Iš: Turto vertinimo teorijos ir praktikos apybraižos 2013. Sud. S. Deveikis. Vilnius: LTVA. P. 48-82.

4. Laurinavičius A., Galinienè B. 2011. Nekilnojamojo turto vystytojas kaip ekonominès veiklos dalyvis. Iš: Turto vertinimo teorijos ir praktikos apybraižos 2010/2011. Sud. S. Deveikis. Vilnius: LTVA. P. 3647.

5. Lietuvos Respublikos Seimo 2002 m. spalio 29 d. nutarimas Nr. IX-1154 „Dèl Lietuvos Respublikos teritorijos bendrojo plano“. Valstybès žinios. 2002. Nr. $110-4852$. 
6. Lietuvos Respublikos Vyriausybès 1992 m. gegužès 12 d. nutarimas Nr. 343 „Dèl specialiųjų žemès ir miško naudojimo sąlygų patvirtinimo". Valstybes žinios. 1992. Nr. 22-652.

7. Lietuvos Respublikos žemès įstatymas $1994 \mathrm{~m}$. balandžio 26 d. Nr. I-446. Valstybés žinios. 1994. Nr. 34-620.

8. Lietuvos Respublikos žemès ūkio paskirties žemès îsigijimo laikinojo įstatymo Nr. IX-1314 pakeitimo įstatymas $2014 \mathrm{~m}$. balandžio $24 \mathrm{~d}$. Nr. XII-854 Valstybés žinios. 2003. Nr. 15-600.

9. Malienė V., Zavadskas E. K., Kaklauskas A., Raslanas S. 1999. Nekilnojamojo turto vertinimas daugiakriteriniu metodu. Iš: STATYBA-CIVIL ENGINEERING. T. V. Nr. 4. P. 272-284.

10. Markšaitis H., Navickienė O. 2012. Tikimybiu teorija ir matematine statistika: elektroninis leidinys. Vilnius: Mykolo Romerio universitetas. 39 p. [žiūrèta 2015-05-26]. Prieiga per internetą: http:// wdn.ipublishcentral.net/association_lithuania_serials/viewinside/31759462611272

11. Ribokas G. 2013. Kai kurie mažiau palankių ūkininkauti teritoriju žemès ūkio intensyvumo aspektai. Geografijos metraštis. T. 46. P. 62-71.

12. Skuodo rajono savivaldybès teritorijos bendrasis planas, patvirtintas Skuodo rajono savivaldybès tarybos 2009 m. lapkričio 26 d. sprendimu Nr. T9217.

13. Tumelionis A. Lyginamojo metodo pataisų apskaičiavimo aktualijos. 2013. Iš: Turto vertinimo teorijos ir praktikos apybraižos 2013. Sud. S. Deveikis. Vilnius: LTVA. P. 38-54.

\section{Rimvydas Gaudèšius, Pranas Aleknavičius}

\section{AGRICULTURAL LAND MARKET ACTIVITY DEPENDING ON PROPERTIES OF LAND PLOTS IN SKUODAS LOCALITY}

Sum $m$ ary

Since 1991 the Republic of Lithuania has been carrying out the land reform, restoring property rights to the nationalized real estate and selling the state land. At the same time, the process of farming transformation is visible. During this period the market activity of private agricultural land increased.

The scientific article identifies the most significant reasons and properties of land plots, which determine activity in the land market. In the study the agrarian area near the city was selected. The scientific study found that most owners of the land actually used only 46 percent of their agricultural land. This fact has influence on the land transfer and the formation of large farms. Also it was found that juristical regulation of agricultural land market could speed up the process of the formation of economic structures and help to avoid wasteful usage of arable land.

Key words: land plots, land market, agricultural land, farm operators 